\title{
Pormestari vai virkajohtaja - miksi kunnan johtamismallin muuttamista harkitaan?
}

\author{
Anni Jäntti, Arto Haveri \& Jenni Airaksinen
}

\begin{abstract}
"Mayor or Manager - Why Changing the Management Model is under Discussion in Municipalities?"
\end{abstract}

The aim of this study is to produce new knowledge on why municipalities consider changing their management model and what contexts and issues lead to such considerations. Based on previous research we first comprise a synthesis about the factors that bring about the need for changing the management model. Then we use it as an analytical tool in analysing our empirical qualitative data, which consist of Finnish news articles. Our findings strengthen and complement the previous research: the changing operational environment as well as dissatisfaction with management and distribution of power are the key issues that bring up considerations for changing the management model. Our empirical data analysis comprehends previous research by revealing new factors, the growing demands for local politicians and practical reasons, that may lead to changes in the management model.

Keywords: mayor, manager, management model, municipalities, Finland

\section{JOHDANTO}

Vuosituhannen vaihteen tienoilla alkanutta ajanjaksoa voi luonnehtia suomalaisten kuntien näkökulmasta suuren murroksen ajaksi. Kuntien toimintaympäristö on muuttunut kiihtyvällä tahdilla, kuntien tehtävämäärä on kasvanut, kunnat eriytyvät yhä voimakkaammin ja joutuvat jatkuvasti etsimään uusia keinoja ekologisesti, sosiaalisesti ja taloudellisesti kestävän tulevaisuuden luomiseksi. Kuntien toimintaym- päristön muuttuessa kasvaa myös tarve pohtia kunnan johtamismallia.

Suomessa pormestarimalli on verrattain uusi ja vielä harvinainen johtamismalli. Eurooppalaisittain tarkasteltuna maamme näyttäytyy melko poikkeuksellisena: kun pormestarimalli on Euroopassa valtavirtaa, Suomessa on perinteisesti kunnan johtohenkilönä ollut pormestarin sijaan viranhaltijana toimiva kunnanjohtaja. Myös Suomessa on kuitenkin viime aikoina käyty runsaasti julkista keskustelua pormestarimallista.

Pormestarimalli kuntajohtamisessa mahdollistui Suomessa vuonna 2006, kun kuntalakia muutettiin siten, että kunta voi valita ykkösjohtajakseen joko viranhaltijana toimivan kunnanjohtajan tai luottamushenkilönä toimivan pormestarin. Lakimuutoksen taustalla oli tarve vahvistaa poliittista johtamista. Osittain lakimuutoksen tarve nousi paikallistasolta, sillä Tampereen kaupunki halusi siirtyä pormestarimalliin.

Sittemmin tätä mahdollisuutta pormestarimalliin on käyttänyt vain muutama kunta. Vuonna 2020 pormestari johtaa kuntaa kuudessa suomalaisessa kunnassa: Helsingissä, Kärkölässä, Pirkkalassa, Puolangalla, Tampereella ja Tuusulassa. Näiden pormestarijohtoisten kuntien lisäksi ainakin Espoossa, Heinolassa, Hämeenlinnassa, Imatralla, Jämsässä, Kokkolassa, Kotkassa, Lahdessa, Nokialla, Oulussa, Porissa, Rovaniemellä, Salossa, Seinäjoella, Turussa, Vantaalla ja Vihdissä on pohdittu pormestarimalliin siirtymistä. Näistä kunnista Lahti ja Turku ovat tehneet päätöksen pormestarimalliin siirtymisestä valtuustokauden 2021-2025 alkaessa, mutta Lahti kumosi päätöksensä vuonna 2020. Pormestarimalli ei siis ole Suomessa ainakaan toistaiseksi saanut kovinkaan laajaa kannatusta, mutta erityisesti suuremmat kaupungit ovat esittäneet kasvavaa kiinnostusta sitä kohtaan. 
Kunnan ylimmän johtajan rooli ja asema kuntaorganisaatiossa vaikuttavat merkittävästi koko johtamisjärjestelmään ja kunnan johtamiseen. Valinnassa kunnanjohtajamallin ja pormestarimallin välillä on kyse paitsi kunnan johtohahmon asemasta ja roolista, myös laajemmasta johtamisjärjestelmää koskevasta muutoksesta. Johtamisjärjestelmän muuttamisella voi olettaa olevan monen tasoisia ja monenlaisia vaikutuksia kunnan poliittiseen ja viranhaltijaorganisaatioon, sekä kunnan toimintatapoihin ja toimintakulttuuriin. (Jäntti, Haveri \& Airaksinen 2021.) Siirtyminen pormestarimalliin onkin toteutettu osana suurempaa kaupungin toimintamallin muutosta esimerkiksi Tampereella, Helsingissä ja Turussa, joissa johtamismallin muutoksen lisäksi on samanaikaisesti uudistettu muutenkin kaupungin organisaatiota.

Suomalaisessa kuntatutkimuksessa pormestarimalliin ja pormestareihin liittyvä tutkimus on vielä varsin vähäistä. Suomalainen pormestaritutkimus on toistaiseksi liittynyt lähinnä Tampereen toimintamallin muutokseen ja sen arviointiin (ks. esim. Hakari 2009, Stenvall \& Airaksinen 2009, Hakari, Stenvall \& Rannisto 2013). Ne harvat pormestariin tai pormestarimalliin liittyvät suomalaiset tutkimukset, joita aihepiiristä on julkaistu, eivät juurikaan käsittele kunnan johtamismallin muuttamiseen liittyviä syitä. Tämän vuoksi myös tämän tutkimuksen viitekehys koostuu pääasiassa muiden maiden pormestarimalleja koskevasta tutkimuksesta. Pormestarimalliin kohdistuvan kiinnostuksen kasvaessa aihepiiriin liittyvälle tutkimukselle on kuitenkin aiempaa enemmän tilausta. Suomalaisten kuntien johtamisen moninaistuessa avautuu myös uusia kuntajohtamisen tutkimukseen liittyviä kysymyksiä ja mahdollisuuksia.

Tämän artikkelin tarkoituksena on tuottaa uutta tietoa siitä, minkälaisissa tilanteissa kunnan johtamismallin muuttamista harkitaan, ja minkälaiset tekijät tuovat esiin tarpeen pohtia kunnan johtamismallin muutosta. Kunnan johtamismallilla tarkoitamme tässä artikkelissa kunnan ylintä johtohenkilöä, joka siis Suomessa voi olla joko kunnanjohtaja (virkajohtaja) tai pormestari. Tosin suuremmissa kaupungeissa kyse on myös apulaisjohtohenkilöistä, jotka voivat olla myös virkajohtaja- tai pormestarinimikkeellä. Pyrkimyksenä on luoda ymmärrystä niistä asioista, joita kunnan johtamismalliin muutostarpeesta keskusteltaessa liitetään.

Tutkimusotteemme on laadullinen, kuvaileva ja uutta ymmärrystä tuottava. Artikkelin teoreettinen kehys rakentuu erityisesti kansainvälisen kuntajohtamistutkimuksen varaan, ja sen tarkoituksena on tarjota viitekehys sen ymmärtämiseksi, minkälaisiin tekijöihin kunnan johtamismallin muuttaminen liitetään. Aiemman tutkimuksen pohjalta tehdään synteesi niistä kansainvälisessä tutkimuskirjallisuudessa esiintyvistä tekijöistä, joiden perusteella johtamismallin muutosta harkitaan tai siihen päädytään. Tätä synteesiä hyödynnetään analyyttisena kehikkona tutkimuksen empiirisen aineiston analysoinnissa.

Tutkimuksen empiirinen aineisto on koottu suomalaisesta kirjoitetusta media-aineistosta. Yhdistämällä aiemman tutkimuksen havaintoja ja empiirisen aineiston analyysin tuloksia artikkelissa vastataan seuraavaan kysymykseen: miksi ja millaisissa tilanteissa kuntien johtamismallin muuttamista harkitaan?

Aluksi kuvaamme johtamismalleihin liittyviä trendejä Euroopassa ja Yhdysvalloissa aiemman tutkimuskirjallisuuden pohjalta. Tämän jälkeen tarkastelemme kansainvälisen tutkimuksen valossa johtamismallin muutokseen vaikuttavia tekijöitä sekä teemme synteesin aiemmasta johtamismallin valinnan perusteluja koskevasta tutkimuksesta. Tämän synteesin perusteella muodostamme analyysikehikon, joka toimii puitteena media-aineistomme laadulliselle sisällönanalyysille. Tämän jälkeen esittelemme mediaaineiston analyysin tulokset. Lopuksi pohdimme kunnan johtamismalliin liittyviä odotuksia ja uskomuksia sekä esitämme johtopäätöksemme kunnan johtamismalleihin liitettävistä merkityksistä.

\section{PORMESTARI JA VIRKAJOHTAJA KUNNAN JOHTOHAHMOINA}

Kun kuntien johtamisjärjestelmiä vertaillaan kansainvälisesti, ensimmäisenä huomio kiinnittyy erilaisten mallien valtavaan variaatioon, joka johtuu sekä paikallishallinnon historiasta, kulttuurista että kansallisvaltioiden erilaisista hallintojärjestelmistä. Euroopassa ja Yhdysvalloissa on käytössä yhtäältä lukuisia erilaisia ns. pormesta- 
rimalleja eli pormestarien johtamia kuntia, ja toisaalta virkajohtamiseen perustuvia kunnanjohtajaperusteisia malleja. Käytämme artikkelissa termiä virkajohtaja viittaamaan kaupungintai kunnanjohtajaan. Euroopassa pormestarien johtamat kunnat ovat selkeästi valtavirta, ja virkajohtajamalli on käytössä lähinnä vain Suomessa, Irlannissa ja Islannissa. Yhdysvalloissa taas kaikkein suurimpia kaupunkeja lukuun ottamatta virkajohtajamalli on nykyään vallitsevampi.

Euroopassa pormestarimallin osalta on tärkeää erottaa kaksi eri päävaihtoehtoa; suoralla kansanvaalilla valittavan pormestarin malli sekä valtuuston valitseman pormestarin malli. Suomessa näistä käytössä on vain valtuuston valitseman pormestarin malli. Valtuuston valitsema pormestari on yleisemminkin tyypillisempi sellaisissa maissa, joissa kunnilla on laaja tehtäväkenttä ja suuri vastuu palvelujen järjestämistä. Pohjoismaissa pormestari on tyypillisesti valtuuston valitsema, kun taas esimerkiksi Saksassa, Ranskassa, Espanjassa ja Italiassa suositaan suoralla vaalilla valittavan pormestarin mallia. Näissä Keski- ja Etelä-Euroopan maissa kuntien tehtäväkenttä on huomattavasti suppeampi kuin Pohjoismaissa.

Kaiken kaikkiaan suoralla vaalilla valittava pormestari on Euroopassa yleisempi kuin valtuuston valitsema pormestari: vuonna 2006 yli kaksi kolmasosaa eurooppalaisista pormestareista oli valittu suoralla vaalilla (Magnier 2006). Joissakin maissa, kuten Alankomaissa, Belgiassa ja Luxemburgissa, pormestarien nimitykset vahvistaa valtion keskushallinto, ja pormestareilla on paikallisen johtajaroolin lisäksi valtiollisia, esimerkiksi väestörekisterin ylläpitoon liittyviä tehtäviä. Yhdysvaltain osalta taas on hyvä huomata, että useimmissa kaupunginjohtajakaupungeissakin on pormestari. Tällöin pormestarin rooli on kuitenkin johtajana heikompi kuin pormestarimallin kaupungeissa, joissakin tapauksissa lähinnä seremoniallinen (Svara 2003).

Kansainvälisen kaupungin- ja kuntajohtajien yhdistyksen kyselyn mukaan vuonna 2011 Yhdysvaltain kunnista reilussa kolmanneksessa oli käytössä pormestarimalli loppujen ollessa virkajohtajan johtamia. Pormestarikunnista lähes kaikissa pormestari valitaan suoralla vaalilla. (ICMA International City/County Management Association: Municipal Form of Government survey 2011.)
Suurin ero amerikkalaisten pormestari- ja virkajohtoisten kaupunkien välillä on siinä, kenellä on kontrolli päivittäisistä hallintokoneiston toimista ja valta tehdä päätöksiä resurssien käytöstä. Kontrolli on joko pormestarilla tai virkajohtajalla, joilla on tyypillisesti erilaiset ammatilliset kannustimet ja poliittiset motivaatiot, jotka voivat - ainakin teoriassa - vaikuttaa siihen, miten kaupunki toteuttaa tehtäviään. Virkajohtaja toimii yhdessä valtuuston kanssa, ja tärkeä osa tätä työtä on tiedon ja päätöksenteon vaihtoehtojen puoluepolitiikasta vapaa tarjonta kaikille valtuutetuille. Pormestarimallissa pormestari on puolestaan merkittävä poliittinen auktoriteetti, joka voi vähentää valtuuston roolia (Kreft 2007, 4).

Viimeisten vuosikymmenien aikana kehitys on Euroopassa kulkenut suoralla vaalilla valittavan pormestarin suuntaan. Etenkin monissa ItäEuroopan maissa, kuten Puolassa ja Romaniassa sekä entisen Itä-Saksan osavaltioissa, on otettu käyttöön malli, jossa pormestari valitaan suoralla kansanvaalilla, mutta sen suosio on lisääntynyt myös läntisen Saksan osavaltioissa ja jonkin verran Britanniassa ja Norjassa. (Ks. esim. Larsen 2002.) Sen sijaan virkajohtajamalliin ei ole juurikaan siirrytty missään maassa 2000-luvun puolella. Eurooppalaista keskustelua käydään lähinnä pormestarien valintatavasta ja muista pormestarien asemaan ja valtaan vaikuttavista tekijöistä kuten riippumattomuudesta ja tehtävistä sekä heidän suhteestaan valtuustoon ja muihin kunnan hallintoelimiin.

Yhdysvalloissa muissa kuin suuremmissa kaupungeissa kehitys on puolestaan kulkenut enemmän pormestarimallista virkajohtajamallin suuntaan (Carr 2014, 673; Choi, Feiock ja Bae 2013). Yli sadan tuhannen asukkaan kaupungeissa muutosta on tapahtunut kumpaankin suuntaan, yhtäältä virkajohtajamallista (councilmanager) pormestarimalliin (mayor-council), ja toisaalta pormestarimallista virkajohtajamalliin. (Svara \& Watson 2010).

Euroopassa, jossa pormestarijohtoisuus on hallitsevassa asemassa ja virkajohtajamalli ennemminkin kuriositeetti, vertailua pormestarija virkajohtajamallin välillä ei varmaankaan ole koettu yhtä mielekkääksi ja tarpeelliseksi kuin Yhdysvalloissa, jossa tämäntyyppistä tutkimusta onkin tehty selvästi enemmän. Eurooppalainen vertaileva tutkimus on enemmänkin ollut kiin- 
nostunut suoralla vaalilla valitun pormestarimallin ja valtuuston valitseman pormestarimallin eroista (ks. esim. Copus 2004; Heinelt, Hlepas, Kuhlmann \& Swianiewicz 2017; Schaap, Daemen \& Ringeling 2009; Wollman 2014) kuin pormestarimallin ja virkajohtajamallin vastakkainasettelusta.

\section{MIKSI KUNNAT HALUAVAT MUUTTAA JOHTAMISMALLIAAN? - SYNTEESI AIEMMASTA TUTKIMUKSESTA}

Kunnan johtamismallin valintaa ja sen muuttamista koskeva aiempi tutkimus on keskittynyt erityisesti yksittäisten maiden tarkasteluun (ks. esim. Baldini 2002; Fenwick \& Elcock 2014; Garmann 2015, Marsh 2012, Sancino \& Castellani 2016; Svara ja Watson 2010; Sweeting \& Hambleton 2020; Wollmann 2014). Tämän aiemman tutkimuksen pohjalta teemme synteesin siitä, minkälaisia tekijöitä liittyy kuntien haluun muuttaa johtamismalliaan. Olemme jaotelleet synteesissä kahteen ryhmään aiemmassa tutkimuskirjallisuudessa esitetyt syyt johtamismallin vaihtamiseen. Näitä syitä ovat:

1) toimintaympäristöön ja sen muutokseen sekä

2) vallanjaon ja johtamisen toimivuuteen liittyvät syyt.

Hasset ja Watson $(2007,141)$ toteavat, että joissakin kaupungeissa näyttää olevan jatkuva jännite ja keskustelu meneillään virkajohtajamallin ja pormestarimallin välillä, kun taas toisissa asia ei herätä juurikaan intohimoja. Jännitekaupungeissa johtamismallin uudistaminen saattaa nousta heilurityyppisesti pinnalle piankin sen jälkeen, kun mallia on viimeksi uudistettu: "Vaikka päätös uudesta rakenteesta on tehty, se ei ole pysyvä". Johtamismallien välinen jännite voi nostaa pormestarimallin ja virkajohtajamallin edut julkiseen keskusteluun milloin tahansa, mutta erityisen otollinen aika keskustelulle on ennen vaaleja, jolloin poliittiset ryhmät käyttävät johtamismallin uudistamista tai säilyttämistä vaaliteemanaan.

Pormestarimallin kasvanut suosio liittyy aiemman kansainvälisen tutkimuksen perusteella kiinteästi kuntajohtamisen muuttuvaan toimintaympäristöön. Toimintaympäristöön ja sen muutokseen liittyvät syyt voivat olla niin paikallisia, kansallisia kuin kansainvälisiä.

Svaran ja Watsonin (2010) mukaan haluun uudistaa johtamismallia vaikuttavat esimerkiksi seuraavat kunnan toimintaympäristöön liittyvät tekijät:

- voimakas kasvu tai sen puute,

- elinkeinoelämän ja median vaikutus sekä

- muut rakenteelliset johtamiseen liittyvät uudistukset.

Kuntien johtamismalliin liittyvä pohdinta saa vahvasti vaikutteita myös kansainvälisestä keskustelusta ja kansainvälisistä esimerkeistä (ks esim. Hambleton \& Sweeting 2004). Pormestarimalliin siirtymistä voidaankin tulkita yhtenä vastauksena kuntien muuttuvaan toimintaympäristöön, jossa talouden globalisaatiolla on suuri merkitys. Tähän liittyy myös uudella tavalla korostunut verkostojen ja kumppanuuden merkityksen kasvu.

Vaikka johtamismallien uudistamisessa haetaankin kansainvälisiä vaikutteita, myös perinteisillä kansallisilla hallintokulttuurin piirteillä on suuri merkitys siihen, minkälaisiin johtamismalleihin kunnissa nojataan. Esimerkiksi Pohjoismaissa kuntajohtaminen on perustunut kollektiiviseen, jaettuun johtamiseen, kun taas pormestarimalli perustuu vahvemmin yksilöjohtamiseen. Tämä vaikuttaa osaltaan pormestarimalliin liittyvään vähäisempään kiinnostukseen Pohjoismaissa, vaikkakin kiinnostus on jonkin verran kasvanut. (Goldsmith \& Larsen 2004.)

Saksassa puolestaan toisen maailmansodan jälkeisellä jaolla miehitysvyöhykkeisiin ja voittajavaltioiden käytännöillä on ollut vaikutuksensa johtamismalleihin eri osavaltioissa (Garmann 2015). Yhdysvalloissa johtamismallin uudistaminen on enemmän esillä erityisesti suurissa kaupungeissa, joissa ongelmat ovat kompleksisempia, väestö on heterogeenisempää ja moniarvoisempaa kuin pienissä kunnissa.

Historian ja kulttuurin lisäksi myös valtakunnan tason poliittisten voimasuhteiden muutoksella on vaikutuksensa kuntien johtamismallien uudistamiseen. Esimerkiksi Isossa-Britanniassa suoralla vaalilla valittavat pormestarit olivat osa David Cameronin johtamien konservatiivien paikallisuutta korostavaa agendaa, ja monet aja- 
tuspajat tukivat ja edistivät ideaa voimakkaasti. (Marsh 2012.)

Edellä mainittujen syiden lisäksi erilaiset tavat hahmottaa kunnan rooli ja merkitys, voivat vaikuttaa siihen, miksi johtamismalleja uudistetaan. Uudenlaiset ajatukset kunnan roolista, julkisten palvelujen järjestämisestä ja kuntajohtamisesta haastavat myös kuntajohtamisen ja herättävät pohdintoja sopivasta johtamismallista (Goldsmith \& Larsen 2004). Kunta on mahdollista nähdä yhtäältä kilpailevien intressien pelikentäksi, tai yhteisöksi, jolla on yhteiset kuntaa kokonaisuutena hyödyttävät arvot ja päämäärät. Ensimmäinen tulkinta korostaa vahvan johtajuuden merkitystä konfliktien ratkaisussa ja kanavoimisessa, koska ryhmät ja yksilöt ajavat vain omaa etuaan. Jälkimmäisessä korostuu tarve tuoda eri ryhmiä yhteen työskentelemään yhdessä, ja jaetun johtajuuden nähdään ilmentävän yhteisiä tavoitteita. Yksilöjohtajuutta painottavat pormestarimallit tukevat vahvoihin yksilöihin perustuvaa johtajuutta, valtuuston merkitystä korostavat virkajohtajamallit taas jaetun johtajuuden ajatusta.

Intressien moninaisuus ja pelikentän monimutkaisuus voisi osittain selittää sitä miksi suuremmissa kaupungeissa käydään enemmän johtamismallin uudistamiseen kohdistuvaa keskustelua ja tehdään aloitteita muutoksista. Pienemmissä kunnissa yhteisöllisyyden kehittyminen on yleensä helpompaa kuin suurissa kaupungeissa, joissa on myös tyypillisesti edustettuna suurempi määrä erilaisia kilpailevia taloudellisia, poliittisia tai ympäristöön liittyviä intressejä.

Keskustelu pormestari- ja virkajohtajamallista kytkeytyy osin myös kuntakokoon. Suomessa (Juntunen \& Leinonen 2007; Leinonen 2010), kuten Yhdysvalloissakin (ks. Svara \& Watson 2010) on ollut tapana ajatella, että pormestarimalli sopii paremmin suuriin kaupunkeihin, kun taas pienemmissä kaupungeissa ja kunnissa virkajohtajamallin on katsottu tuottavan parempia tuloksia. Tätä näkemystä on Suomessa perusteltu esimerkiksi suurempien kaupunkien laajemmilla tehtävillä ja haasteilla sekä poliittisilla ristiriidoilla. Koulutettujen virkajohtajien merkitystä pienemmissä kunnissa on puolestaan perusteltu $\mathrm{mm}$. hallinto- ja talousasiantuntemuksella, jota pienten kuntien valtuustoista ei välttämättä löydy samaan tapaan kuin kaupungeista.
Vastaavasti Yhdysvalloissa käydään yhä keskustelua siitä, sopiiko virkajohtajamalli lainkaan kaikkein suurimpiin kaupunkeihin.

Toimintaympäristöön ja sen muutokseen liittyvien syiden lisäksi myös vallanjaon ja johtamisen toimimattomuus vaikuttaa siihen, että johtamismallin muuttaminen nousee keskusteluun. Kansainvälisessä tutkimuskirjallisuudessa johtamismallin muutospohdintojen taustalta esiin nousevat vallanjakoon ja johtamiseen liittyvät epäselvyydet ja ongelmat sekä valtaepätasapaino poliittisen ja viranhaltijajohdon välillä. Esimerkiksi Svaran ja Watsonin (2010) yhdysvaltalaisiin havaintoihin perustuvassa tutkimuksessa näitä vallanjaon ja johtamisen toimivuuteen liittyviä tekijöitä ovat:

- epävakaa poliittinen ilmapiiri,

- kokemus kunnanjohtajan tai pormestarin epäonnistumisesta,

- voimakkaiden poliittisten johtajien aloitteellisuus sekä

- muilta kunnilta saadut positiiviset esimerkit mallin uudistamisesta.

Johtamiseen liittyvät ongelmat ovat olleet pontimena johtamismallin vaihtamiseen myös muissa maissa. Esimerkiksi Saksassa keskustelu johtamismallin toimivuudesta on liittynyt yhtäältä demokratiavajeeseen sekä demokraattisen päätöksenteon ja johtamisen ongelmiin, toisaalta on haluttu löytää ratkaisuja kuntien toimintakykyyn liittyviin ongelmiin, kuten talousvaikeuksiin (Wollmann 2014).

Isossa-Britanniassa suoralla vaalilla valittava pormestari ja tarve johtamismallin muutokselle on noussut keskusteluun vastauksena kuntien johtamisen ongelmiin. Tässä keskustelussa pormestarimalliin siirtymistä on valtakunnan tasolla halki puoluekentän pidetty johtamisongelmien ratkaisuna. Paikallisella tasolla pormestarimallista ei kuitenkaan ole kovin monessa kunnassa innostuttu. Niissä kunnissa, joissa pormestarimalliin on siirrytty, taustalla ovat yleensä olleet valtakunnallisessa politiikassa lausuttujen yleistavoitteiden sijaan ennemminkin paikalliset erityispiirteet, kuten jokin paikallinen johtamisen kriisi, kuntalaisten voimakas tahtotila, tai korkean profiilin pormestariehdokas. (Fenwick \& Elcock 2014.)

Vuosina 2011-2012 noin 50 brittiläisessä kunnassa järjestettiin kunnallinen kansanäänes- 
tys pormestarimalliin siirtymisestä. Näistä vain 15 kunnassa päädyttiin siirtymään pormestarimalliin. Yksiselitteistä ja selkeää vastausta siihen, miksi pormestarimalliin ei haluttu siirtyä, ei ole. Yksi mahdollinen syy on se, että muutostarvetta ei paikallisesti koettu suureksi, jos kunnassa ei ollut selkeitä johtamiseen liittyviä ongelmia tai kriisejä. Lisäksi paikallisvaalien matalan äänestysaktiivisuuden ja sen taustalla olevan vähäisen kiinnostuksen arvellaan osaltaan vaikuttaneen tulokseen. Brittikokemusten perusteella kiinnostus pormestarimallia kohtaan on selvästi vahvempaa valtakunnan tason keskusteluissa kuin paikallisella tasolla. (Fenwick \& Elcock 2014; Sweeting \& Hambleton 2020.)

Italiassa pormestarin valitseminen suoralla vaalilla tuli mahdolliseksi vuonna 1993 . Kuten monissa muissakin maissa, myös Italiassa taustalla olivat kuntien johtamiseen ja vallanjakoon liittyneet ongelmat. Pormestarimallin käyttöönottoon johtivat korruptiotapaukset, puoluepolitiikan levittäytyminen hallintoon ja kaipuu vahvaan johtajuuteen. Taustalla oli myös pitkään jatkunutta poliittista epävakautta ja valtakunnan politiikan pyrkimyksiä vaikuttaa paikallishallintoon. Vuosina 1972-1989 suurin osa italialaisten kuntien hallituksista pysyi kasassa korkeintaan vuoden, mikä vaikeutti johtamisen pitkäjänteisyyttä. (Baldini 2002.) Ongelmia ja epäselvyyksiä oli myös valta- ja vastuukysymyksissä (Sancino \& Castellani 2016). Nämä monet johtamiseen ja vallanjakoon liittyvät ongelmat yhdessä herättivät tarpeen pohtia johtamismallin muuttamista.

Kysymys johtamismallista ja sen muuttamisesta kytkeytyy luonnollisesti myös kysymykseen vallasta. On esimerkiksi yleistä, että poliittiset johtajat käyttävät aikaa ja energiaa saadakseen aikaan muutoksen virkajohtajamallista pormestarimalliin, jotta he voisivat lisätä omaa vaikutusvaltaansa. Sen sijaan on harvinaista löytää pormestari, joka ajaa muutosta pormestarimallista virkajohtajamalliin, tosin yksi tällainenkin tapaus löytyi Svaran ja Watsonin (2010) USA:n kaupunkeja käsittelevästä tutkimusaineistosta.

Aiemman kansainvälisen tutkimuksen perusteella voidaan siis todeta, että johtamismallien muutokseen liittyvät syyt yhtäältä kuntien toimintaympäristön muutokseen ja toisaalta vallanjaon ja johtamisen toimivuuteen kunnan sisällä. Kuntien toimintaympäristössä kasvun kiihtyminen tai hiipuminen, kansallinen politiikka ja kansainväliset esimerkit voivat toimia taustana johtamismallin muutokselle. Kuntien sisäisistä tekijöistä puolestaan vallanjaon ja johtamisen toimivuuteen liittyvät kysymykset ajavat pohtimaan johtamismallin muuttamista.

\section{LAADULLINEN SISÄLLÖNANALYYSI SUOMALAISESTA MEDIA-AINEISTOSTA}

Tutkimuksen empiirinen aineisto koottiin suomalaisesta kirjoitetusta media-aineistosta. Aineistona olivat Ylen ja Helsingin Sanomien verkkomediassa julkaistut tekstit, joissa käsitellään kuntien johtamismallin muutosta ja etenkin keskustelua pormestarimallista. Aineistoksi valitsimme media-aineiston, koska sen avulla pystyimme perehtymään monen eri kunnan johtamismallikeskusteluihin ja tavoittamaan ne julkiseen keskusteluun nousseet keskeiset syyt ja tilanteet, joissa kunnan johtamismallin muutosta harkitaan.

Vaihtoehtoisena aineistona harkitsimme myös kunnanvaltuustojen keskustelupöytäkirjoja, mutta näitä ei ole saatavilla kaikista kunnista, joissa johtamismallin muutosta on harkittu. Lisäksi pöytäkirja-aineiston rajoitteena on, että johtamismallin muuttamista koskevaa keskustelua ei välttämättä käydä toimielimissä, erityisesti jos kyseessä on esimerkiksi yksittäisen valtuutetun tai poliittisen ryhmän ehdotus tai keskustelunavaus, jolloin asia ei välttämättä etene virallisiin keskusteluihin. Joka tapauksessa keskustelua käydään pöytäkirjan ulkopuolella myös silloin kun asiaa käsitellään virallisissa toimielimissä. Aineistona olisi ollut mahdollista käyttää myös haastattelu- tai kyselyaineistoa, mutta niiden keräämiseen ei tutkimusekonomisista syistä ryhdytty, kun media-aineiston katsottiin sopivan riittävän hyvin tutkimusasetelmaan.

Media-aineiston rajoitteena voi pitää sitä, että aineisto perustuu tekstin tuottaneiden toimittajien tulkintaan käydystä keskustelusta, mikä voi osin värittää tai muuttaa kuvaa tästä keskustelusta. Kuitenkin aineistona olevissa mediateksteissä on käytetty paljon esimerkiksi poliitikkojen suoria sitaatteja, mikä vähentää tätä riskiä.

Aineisto päätettiin rajata Ylen ja Helsingin Sanomien tuottamaan aineistoon, sillä niissä oli tarjolla lukumääräisesti eniten aineistoa ja nämä mediat ovat luonteeltaan valtakunnallisia ja kat- 
tavat siten useita alueita ja kuntia. Erityisesti Ylen tuottamassa aineistossa käsiteltiin aihetta monien eri kuntien näkökulmista, minkä voi olettaa rikastavan ja monipuolistavan aineistoa. Aineisto koottiin Ylen ja Helsingin Sanomien internet-sivuilta ko. medioiden omien hakutoimintojen avulla. Julkaisujen aikaväli rajattiin alkamaan vuodesta 2000 ja loppumaan vuoteen 2020. Aineistosta rajattiin tarkasteltavaksi sellaiset tekstit, joissa käsitellään johtamismallin vaihtamista tai sen harkitsemista jossakin suomalaisessa kunnassa. Aineiston vanhimmat tekstit ovat vuodelta 2001 ja uusimmat vuodelta 2020. Aineisto koostui yhteensä 92 mediatekstistä. Yleltä on aineistossa yhteensä 45 mediatekstiä, joista kaikki ovat uutisia ja Helsingin Sanomilta 47 mediatekstiä, joista 28 on uutisia, 10 pääkirjoituksia tai kolumneja ja loput analyyseja tai taustoittavia tekstejä. Helsingin Sanomien jutuista 13 on julkaistu 2000-luvulla, loput 2010luvulla. Ylen aineisto on lähes kokonaan 2010luvulta, kaksi uutista on 2000-luvulta (v. 2009) ja kaksi uutista 2020-luvulta. Analyysin tulokset perustuvat em. aineistoon kokonaisuutena. Lähdeluettelossa on mainittu ne mediatekstit, joihin tässä artikkelissa on suoraan viitattu.

Koottu media-aineisto analysoitiin sisällönanalyysin keinoin aiemman tutkimuksen perusteella muodostamamme analyysikehikon avulla. Analyysissa yhdistettiin induktiivista ja deduktiivista päättelyä (ks. esim. Fereday \& MuirCochrane 2006). Aineistoa analysoitiin tarkastellen sitä, miksi johtamismallin muutosta harkitaan tai siihen päädytään. Tähän liittyen aineistoa peilattiin teoriaan perustuen analyysikehikon ohjaamana toimintaympäristöön ja sen muutokseen liittyviin syihin sekä vallanjaon ja johtamisen toimivuuteen liittyviin syihin. Lisäksi analyysivaiheessa koottiin yhteen myös mahdollisia muita kuin analyysikehikon esittämiä syitä.

Analyysiprosessi aloitettiin lukemalla koottu aineisto huolellisesti läpi, minkä jälkeen aineistoa koodattiin Atlas.ti-ohjelman avulla pelkistettyihin ilmauksiin kunnan johtamismallin muutokseen liittyvistä syistä ja tilanteista. Aineistosta muodostetut 133 pelkistettyä ilmausta kiinnittyivät 292 aineistositaattiin. Pelkistetyt ilmaukset luokiteltiin neljään pääkategoriaan, jotka esitellään seuraavassa luvussa.
Analyysivaiheessa aineisto alkoi kyllääntyä, eli se ei enää tuottanut uusia näkökulmia, minkä vuoksi tulkitsimme sen olevan riittävän kattava. Aineiston kattavuuden varmistamiseksi kokosimme lisäksi samoja kriteereitä käyttäen aineistoa myös Etelä-Suomen Sanomista (yhdeksän mediatekstiä), Kalevasta (16 mediatekstiä) ja Turun Sanomista (10 mediatekstiä). Tämä aineisto luettiin huolellisesti läpi, mutta koska se ei tuottanut uusia näkökulmia jo muodostettuihin kategorioihin, se jätettiin varsinaisen analyysin ulkopuolelle.

\section{ANALYYSIN TULOKSET}

Suomalaisen media-aineiston analyysissa muodostimme luokittelun avulla neljä kategoriaa kuvaamaan niitä syitä, joiden vuoksi johtamismallin muutosta aletaan kunnassa pohtia. Nämä kategoriat ovat:

1) toimintaympäristön muutos,

2) luottamushenkilötyön vaativuuden kasvu ja paikallisen poliittisen johtamisen ammattimaistuminen

3) tyytymättömyys johtamiseen ja vallanjakoon sekä

4) käytännölliset syyt.

Toimintaympäristöön muutokseen liittyvät syyt sekä tyytymättömyys johtamiseen ja vallanjakoon johtamismallin muutoksen pontimena olivat samansuuntaisia aiemman tutkimuksen havaintojen kanssa. Sen sijaan luottamushenkilötyön vaativuuden kasvu ja paikallisen poliittisen johtamisen ammattimaistuminen sekä käytännölliset syyt eivät nousseet esiin aiemmasta tutkimuksesta.

Seuraavassa kuvaamme media-aineiston analyysin tulokset kategoria kerrallaan. Tulosten yhteydessä esitetään aineistositaatteja, jotka on valittu siten, että ne valottaisivat mahdollisimman hyvin tekemiämme tulkintoja.

\section{Toimintaympäristön muutos}

Johtamismallin muutostarpeen taustalla vaikuttaa kuntien toimintaympäristön muutos niin kansainvälisellä, kansallisella, alueellisella kuin paikallisella tasolla. Tämän aineiston perusteella toimintaympäristön muutos näyttäytyy var- 
sin harvoin suorana sysäyksenä johtamismallin muutospohdintoihin, joskin muutos voi vaikuttaa taustalla epäsuorasti. Kuitenkin aineistossa on myös joitakin suoriakin kytkentöjä toimintaympäristön ja johtamismallin muutoksen välillä.

Kansainväliset vaikutteet, kuten johtamisoppien muuttuminen tai kansainvälisten kumppaneiden kokemukset johtamismalleista ja niiden muuttamisesta voivat herättää mielenkiintoa paikallistasolla ja käynnistää pohdintoja oman kunnan johtamismallin muutostarpeesta. Johtamismallin muutostarve voi kytkeytyä esimerkiksi ajatukseen eurooppalaisesta kuntajohtamisesta. Tarvetta johtamismallin muuttamiselle on perusteltu esimerkiksi sillä, että "pormestarimalli on laajalti käytössä Euroopassa", ja että näin tarkasteluna voidaan pitää suomalaista virkajohtajamallia poikkeuksellisena ja erikoisenakin: "[s]uomalainen kunnanjohtaja on lajissaan ainutlaatuinen, eurooppalainen kummajainen" (Yle/Hjelt 2015).

Kansainvälisen keskustelun ja vaikutteiden lisäksi johtamismallin muuttamisessa merkitystä on sillä, mitä tapahtuu kansallisesti. Kansallisen tason muutokset liittyvät erityisesti kansallisiin hallinnonuudistuksiin tai kuntia koskevan lainsäädännön muutoksiin.

Yksi viime vuosien isoista kuntien toimintaympäristön ja roolin muutokseen liittyvistä uudistussuunnitelmista Suomessa on ollut useammankin hallituksen kaavailema valtakunnallinen sosiaali- ja terveydenhuollon uudistus. Esimerkiksi Tuusulassa "[y]ksi sysäys johtamismuutoksille on sote-uudistus: kun sosiaali- ja terveyspalvelut irtoavat kuntien hoidosta, muuttuu kuntien rooli." (Yle/Turtola 2016). Kunnan roolin muutoksen lisäksi myös kuntapoliitikkojen roolin arvellaan sote-uudistuksen myötä muuttuvan, mikä voi osaltaan olla pontimena johtamismallin muutokseen. Tämä on noussut esiin esimerkiksi Rovaniemellä: "Poliitikkojen merkitys muuttuu uuden sote-mallin myötä. -- . Rovaniemen perussuomalaisten mukaan kuntiin tarvitaan nyt poliitikkoja, jotka sitoutuvat tehtäväänsä." (Yle/Haapanen 2016).

Muiden kuntien esimerkeillä ja mediassa esillä olevalla keskustelulla on vähintäänkin kiinnostusta herättävä vaikutus johtamismallin vaihtamiseen. Pormestarimallin yleistyessä kiinnostus voi lisääntyä etenkin muiden kuntien myönteisten kokemusten kannustamana. Esimerkiksi Nokialla on pohdittu pormestarimalliin siirtymistä naapurikuntien kokemusten myötä. "Nokian kaupunginvaltuuston puheenjohtaja Jari Haapaniemi (kok.) pitää silti pormestarimallia mahdollisena. Kyllä se voisi meillekin olla dynaaminen vaihtoehto. Tampereelta ja Pirkkalasta saadut viestit olivat hyvin rohkaisevia." (Yle/Matson-Mäkelä 2013).

Toimintaympäristön muutos on tulkittavissa suomalaisessa keskustelussa erityisesti taustalla olevaksi tekijäksi, joka omalta osaltaan vaikuttaa siihen, että johtamismallin muutosta aletaan kunnassa pohtia. Osittain kyse on rakenteellisista puitteista, joissa kuntia johdetaan ja osittain puolestaan kyse on esimerkkien kautta tulevista kansainvälisistä tai kansallisista impulsseista. Toimintaympäristön muutos ei siis näyttäydy suorana, yksittäisenä muutokseen johtavana tekijänä, vaan sillä on epäsuorempi vaikutus.

\section{Luottamushenkilötyön vaativuuden kasvu ja paikallisen poliittisen johtamisen ammattimaistuminen}

Toimintaympäristön muutos vaikuttaa osaltaan luottamushenkilötyön vaativuuden kasvuun, osin suoraan, osin epäsuorasti. Luottamushenkilötyöhön liittyvät muutokset ja siihen kohdistuvat kasvavat vaatimukset ovat aineistomme valossa yksi keskeinen syy siihen, miksi johtamismallin muutosta kunnassa ylipäänsä aletaan pohtia. Kokemukset luottamushenkilötyön vaativuuden kasvusta ja luottamushenkilötyön edellytykset korostuvat aineistossamme täydentäen ja syventäen aiempaa johtamismallitutkimusta. Johtamismallin muutostarve suomalaisissa kunnissa kiteytyykin usein keskusteluun luottamushenkilötyön edellytyksistä ja etenkin näiden edellytysten puutteesta.

Luottamushenkilötyö on aikaa vievää. Erityisesti johtavat poliitikot, kuten valtuuston ja hallituksen puheenjohtajat käyttävät luottamushenkilötyön hoitamiseen huomattavan paljon aikaa, vaikka suuri osa heistä työskentelee kokopäivätoimisesti samalla kun hoitaa kunnallista luottamustehtävää. Luottamushenkilötyö - etenkin johtavien luottamushenkilöiden tehtävät - koetaan myös paikoin raskaiksi ja sitoviksi. Johtavilla luottamushenkilöillä on paljon 
vastuuta kannettavanaan ja useita erilaisia vuorovaikutuksen rajapintoja hoidettavanaan aina kuntayhteistyöstä omiin kuntalaisiin.

"Suurissa kaupungeissa etenkin kaupunginvaltuuston ja -hallituksen puheenjohtajan pesteissä riittäisi tekemistä täyden työviikon edestä. 'Pääkaupunkiseudun yhteistyön tiivistyminen on merkinnyt aivan uudenlaista ajankäytöllistä haastetta keskeisille luottamushenkilöille', Vantaan kaupunginhallituksen puheenjohtaja Markku Jääskeläinen (sd) toteaa." (HS/Moisio 2007.)

Luottamushenkilötyön vaatimukset ovat kasvaneet kuntien tehtävien laajentumisen, asioiden monimutkaistumisen ja käytettävissä olevan tiedon määrän kasvun vuoksi. Esimerkiksi päätöksentekoon liittyvään valmistautumiseen ja asioihin perehtymiseen ei ole aina riittävästi aikaa eikä mahdollisuuksia. Pormestarimallin on arveltu voivan tuoda ratkaisun tähän asiaan." [Kokoomuksen] [r]yhmän puheenjohtaja Kai Holmbergin mukaan pormestarimalli voisi olla kuitenkin yksi keino vähentää kaupungin johtavien luottamusmiesten työtaakkaa" (Yle/ Lassheikki 2012).

Luottamushenkilötyön vaatimusten kasvu onkin ajanut kuntia etsimään ratkaisuja luottamushenkilötyön edellytysten parantamiseen. Pormestarimalli on tässä keskustelussa nähty yhtenä mahdollisena ratkaisuna. Lisäksi kunnissa on vahvistettu luottamushenkilöiden mahdollisuuksia hoitaa tehtäviään osa-aikaisesti tai kokoaikaisesti palkallisina luottamushenkilöinä. Palkallisiin ammattipoliitikkoihin liittyvät kokemukset ja voimistuva keskustelu paikallispolitiikan ammattimaistumisesta voivat myös toimia siltana pormestarimalliin. Esimerkiksi pormestarimalliin siirtymisestä päättäneillä Turulla ja Lahdella on ollut ensin kokopäivätoimiset kaupunginhallituksen puheenjohtajat. Yleisemmin voidaan luonnehtia, että paikallispolitiikan ammattimaistuminen etenee päätoimisten luottamushenkilöiden tehtävien kehittämisen kautta. Esimerkiksi Oulussa pormestaripohdintoja kiihdyttivät kokemukset palkallisista osa- ja kokoaikaisista luottamushenkilöistä: "[Ammattipoliitikko]järjestelmästä saadut kokemukset ovat kääntämässä poliittisten päättäjien mieliä pormestarimallille suosiollisiksi” (Yle/Sipola 2017).

\section{Tyytymättömyys johtamiseen ja vallanjakoon}

Aiemman tutkimuskirjallisuuden perusteella yhtenä syyryppäänä johtamismallin vaihtamiseen ovat johtamiseen ja vallanjakoon liittyvät ongelmat. Analyysimme suomalaisesta mediaaineistosta vahvistaa näitä aiemman tutkimuksen havaintoja. Myös suomalaisessa keskustelussa esiin nousee tyytymättömyys johtamiseen sekä vallanjakoon luottamushenkilöiden ja viranhaltijoiden välillä.

Taustalla voi olla esimerkiksi luottamushenkilöiden ja kunnanjohtajan välisiä ristiriitoja tai viranhaltijoiden ja luottamushenkilöiden välisiä näkemyseroja, joihin ratkaisuksi mietitään johtamismallin muuttamista. Tilanne voi myös olla poliittisesti tulehtunut puolueiden välillä tai puolueen sisällä, mikä heijastuu myös viranhaltijoiden ja luottamushenkilöiden suhteeseen ja kunnan johtamiseen. Esimerkiksi Puolangalla pormestarimalliin siirtymisen taustalla olivat kunnan poliittisen ja viranhaltijajohdon väliset ristiriidat. Tuusulan pormestarimallikaavailujen tulkittiin puolestaan olevan seurausta pitkään jatkuneista poliittisista ongelmista: "- Tuusulassa on ollut varsin tulehtunut poliittinen tilanne viimeiset neljä vuotta. Täällä on yritetty erotustoimilla siirtää kunnanjohtajaa sivuun. Kun siinä ei onnistuttu, on lähdetty ajamaan pormestarimallia, joka siirtää kunnanjohtajan sivuun. --, [Tuusulan kunnanvaltuuston varapuheenjohtaja Lauri] Untamo summaa." (Yle/Vesalainen \& Sarolahti 2017.)

Ajatus johtamismallin muuttamisesta voi kummuta poliitikkojen käytännön tyytymättömyydestä kunnanjohtajaan tai muihin johtaviin viranhaltijoihin sekä heidän johtamistapaansa tai valmisteluunsa. Esimerkiksi Espoossa vihreät ovat esittäneet pormestarimalliin siirtymistä, koska heidän mielestään "kaupungin johtavat virkamiehet vetävät isoja päätöksiä haluamaansa suuntaan" (Yle Uusimaa 2009). Kotkassa puolestaan perussuomalaiset ovat esittäneet johtamismallin muuttamista sen vuoksi, että perussuomalaisten mielestä "kaupunginjohto elää leveästi veronmaksajien rahoilla samalla kun kaupunki yrittää säästää” (Yle/Joki 2012).

Johtamismallin muutostarpeen arviointi voi tulla ajankohtaiseksi myös siitä syystä, että vallanjaon ei katsota toimivan riittävän hyvin luot- 
tamushenkilö- ja viranhaltijajohdon välillä, mikä heijastuu kaupungin päätöksentekokykyyn. Vallanjaon ongelmien voidaan kokea heikentävän kaupungin tehokkuutta tai politikkojen kykyä ohjata kaupungin toimintaa. Esimerkiksi Turussa kaupunginjohtajamallin "suurin ongelma on [Turun kaupunginhallituksen puheenjohtaja Olli A.] Mannin mukaan poliittisen päätöksentehon tehottomuus. --. 'Kaupungin poliittinen johto ei ole ollut tarpeeksi vahva johtamaan tätä apparaattia. Nykyisen hallintomallin toinen kriittinen kohta on virkamieskunta, jossa asiat eivät aina etene. Siellä tahtoo olla vähän italialaista meininkiä, Manni arvioi." (HS/Lehtinen 2015.) Muutostarve voi lähteä myös tilanteesta, jossa luottamushenkilöt kokevat voimattomuutta, koska viranhaltijoille on siirtynyt liikaa valtaa. Tätä valtaa yritetään johtamismallin muutoksen avulla palauttaa luottamushenkilöille. Esimerkiksi Helsingissä (HS/Laitinen 2015) ja Rovaniemellä (Yle/Haapanen 2016) johtamismallin muutospohdintojen taustalla ovat olleet juuri luottamushenkilöiden kokemat valtaongelmat.

Tyytymättömyys johtamiseen ja vallanjakoon voi liittyä myös johtavien viranhaltijoiden valintaan ja siinä erityisesti poliittisiin virkanimityksiin. Pitkissä virkasuhteissa olevat poliittisin perustein valitut viranhaltijat koetaan ongelmalliseksi etenkin poliittisten voimasuhteiden muuttuessa vaalien myötä. Kun johtavien viranhaltijoiden paikat on jaettu puolueiden kesken eivätkä viranhaltijoiden toimikaudet noudattele kunnallisvaalikausia, voi syntyä tilanteita, joissa johtajapaikkojen jako ei vastaakaan valtuuston poliittisia voimasuhteita.

Keskustelua johtamispaikkojen poliittisuudesta on käyty etenkin suuremmissa kaupungeissa ja erityisesti Helsingissä, jossa ennen pormestarimalliin siirtymistä kaupunginjohtajan ja apulaiskaupunginjohtajien määräaikaisten virkojen kohdistumisesta oli sovittu puolueiden kesken. Toistuvat ristiriidat ja tulkintaerimielisyydet apulaiskaupunginjohtajien valinnassa olivat yhtenä pontimena johtamismallin muuttamisen taustalla. "Uudistusta on vauhdittanut apulaiskaupunginjohtajien valinnoista kummunnut kritiikki. Veronika Honkasalo (vas) luonnehti viimeaikaisia valintoja 'hämäräksi systeemiksi'. 'Se on syönyt poliittista luottamusta meiltä kaikilta. Kaupunkilaisten silmissä olemme kaikki olleet osa tätä mätää tuolileikkiä, Honkasalo epäili.” (HS/ Salomaa 2016; Helsingin apulaiskaupunginjohtajavalintoihin liittyvistä ongelmista ks. myös esim. Yle/Frilander 2012, HS/Laitinen 2015.) Media-aineistossa näkyy kuitenkin, miten avoimesti johtajavalintojen poliittisuudesta on Helsingissä keskusteltu: "Demarien ajatus on, että myös seuraava kaupunkisuunnittelun apulaiskaupunginjohtaja tulee Sdp:n riveistä. - Siitä on sopimus, että se kuuluu meille. Kyllä se on ihan selkeä juttu, Sdp:n valtuustoryhmän puheenjohtaja Kai Kalima kertoo." Samassa artikkelissa mainitaan myös, että: "Vihreät ovat olleet jo pitkään tyytymättömiä edustukseensa Helsingin johtajistossa." (HS/Jokinen 2007.)

Poliittisia viranhaltijajohtajavalintoja on pidetty ongelmallisina myös niihin liittyvien pätevyysepäselvyyksien vuoksi. Vaikka viranhaltija on periaatteessa valittu hoitamaan tehtäväänsä puolueettomasti ja ansioituneisuuden perusteella, käytännössä puoluetausta on voinut näkyä vahvastikin kunnan johtamisessa. "[Apulaiskaupunginjohtaja Pekka] Sauri pitää nykyistä apulaiskaupungintehtäväänsä ristiriitaisena. - Sehän on ristiriitainen tehtävä sikäli, että nykyään kaupunginjohtajat ja apulaiskaupunginjohtajat on juridisesti virkamiehiä, ja kuitenkin meidän nimen perässä on suluissa puoluekanta." (Yle/ Koskinen 2016.) Virkajohtajien poliittisuus on siis kahdesta suunnasta vaikuttanut siihen, että johtamismallia on haluttu muuttaa. Yhtäältä ristiriitaisuudet ja "tuolileikki" sekä pätevyyteen liittyvät epäselvyydet ovat vaikuttaneet muutostarpeena ja toisaalta olemassa oleva poliittisuus on haluttu tehdä pormestarimalliin siirtymisen avulla näkyväksi.

\section{Käytännölliset syyt}

Aiemman tutkimuskirjallisuuden perusteella johtamismallin muutosta aletaan pohtia toimintaympäristön muutoksen sekä johtamiseen ja vallanjakoon liittyvien ongelmien vuoksi. Nämä syyt löytyvät analyysimme perusteella myös suomalaisesta johtamismallin muuttamista koskevasta keskustelusta. Näiden lisäksi suomalaisen media-aineiston analyysi osoittaa, että tilanteet, joissa johtamismallin muuttamista ja eri vaihtoehtoja harkitaan, voivat olla myös varsin käytännöllisiä. Näitä tilanteita voi luonnehtia aikaikkunan avautumisena, jossa usein varsin 
intohimottomasti tarkastellaan erilaisia vaihtoehtoja omaan kuntaan sopivan johtamismallin kehittämiseksi. Tällaiseen tilanteeseen voidaan päätyä, kun kunnanjohtaja on lähtenyt tai on lähdössä kunnasta. Taustalla voi tosin olla myös dramaattisempi prosessi: kunnan poliittisen ja viranhaltijajohdon ristiriidoista johtuva kunnanjohtajan eroaminen. Kyse voi olla myös tilanteesta, jossa kunnanjohtaja on eläköitymässä; näin on ollut esimerkiksi Hämeenlinnassa (Yle/ Mustonen 2019), Kokkolassa (Yle/Kivioja 2015) ja Seinäjoella (Yle/Niemistö 2019). Toisinaan taustalla puolestaan on kunnanjohtajan siirtyminen toisiin tehtäviin, kuten on ollut esimerkiksi Nokialla (Yle/Matson-Mäkelä 2013) ja Kärkölässä, jossa jo aiemmin esillä ollut ajatus pormestarimallista nousi uudelleen esiin johtajatilanteen muuttuessa: "[Kärkölä-ryhmän valtuustoryhmän puheenjohtaja] Tapani Suokkaan mukaan keskustelua pormestarimallin käyttöön ottamisesta Kärkölässä on käyty heti kunnallisvaalien jälkeen. Silloin aihe ei kuitenkaan ollut ajankohtainen. Pitkäaikaisen kunnanjohtaja Seppo Huldénin siirtyessä muutosjohtajaksi asia nousi uudelleen esiin." (Yle/Turtola 2017).

Johtamismallin pohtiminen voi käytännöllisistä syistä nousta agendalle, kun työn alla on yleisemmin johtamisen kehittäminen kunnassa. Tällöin on luontevaa ottaa tarkasteluun kunnan johtaminen laajasti. Kyseessä voi olla esimerkiksi kunnan strategiatyö, jonka yhteydessä pohditaan myös sopivaa johtamismallia. Näin tapahtui vuosituhannen alun Vihdissä (HS/Saarelainen 2001). Pormestarimallin käyttöönottoa on esitetty selvitettäväksi samassa yhteydessä, kun kunnan luottamushenkilöorganisaatiota on muutenkin uudistettu. Salossa asian nosti esille paikallinen vihreiden ryhmä: "Vihreiden mielestä osana alkavaa luottamushenkilöorganisaation uudistusta Salossa pitäisi selvittää pormestarimalliin siirtymisen edellytykset." (Yle/ Hjelt 2015). Rovaniemellä puolestaan perussuomalaiset esittivät johtamismallin muuttamista: "Rovaniemen kaupunginhallitus laatii parhaillaan esitystä uudesta luottamusmiesorganisaatiosta. Rovaniemen perussuomalaisten mielestä pormestarihallinnon luominen sopii tähän saumaan hyvin." (Yle/Haapanen 2016).

\section{JOHTOPÄÄTÖKSET}

Tämän tutkimuksen tarkoituksena on ollut tuottaa uutta tietoa siitä, minkälaisissa tilanteissa kunnan johtamismallin muuttamista harkitaan ja minkälaiset tekijät tuovat esiin tarpeen pohtia kunnan johtamismallin muuttamista.

Aiempaa kansainvälistä tutkimusta kokoavan synteesimme perusteella kunnan johtamismallin muuttaminen nousee agendalle toimintaympäristön ja sen muutoksen sekä vallanjakoon ja johtamiseen liittyvien ongelmien vuoksi. Empiirinen analyysimme kunnan johtamismallien muuttamista koskevasta suomalaisesta media-aineistosta vahvistaa, syventää ja täydentää näitä aiemman tutkimuksen tuloksia. Tässä johtopäätösluvussa esitämme yhteenvedon analyysista ja peilaamme sitä aiemman tutkimuksen perusteella muodostamaamme synteesiin.

Kunnan johtamismallin muutosta koskevan suomalaisen media-aineiston analyysimme tuo näkyväksi ne erilaiset syyt ja tilanteet, joiden myötä johtamismallin muutos nousee yleisempään keskusteluun. (ks. kuvio 1). Toimintaympäristön muutos sekä johtamiseen ja vallanjakoon liittyvä tyytymättömyys ovat läsnä niin aiemmassa tutkimuksessa (esim. Svara \& Watson 2010) kuin suomalaisessa keskustelussa. Nämä eurooppalaiseen ja yhdysvaltalaiseen keskusteluun kiinnittyvät tekijät kuvaavat kunnan johtamismallin muutostarpeen universaaleja taustoja. Näiden yleisempien syiden lisäksi empiirinen analyysimme täydentää aiempaa tutkimusta tuoden esiin myös luottamushenkilötyön vaativuuden kasvun sekä käytännölliset syyt, joiden vuoksi kunnan johtamismallin muuttaminen nousee esiin. Analyysimme tulokset siis vahvistavat osaltaan aiemman kansainvälisen tutkimuksen havaintoja kunnan johtamismallin muuttamiseen tai muutostarpeen esiin nostamiseen johtavista tekijöistä, mutta empiirinen analyysimme myös syventää ja laajentaa aikaisempaa tutkimusta tuoden esiin lisää syitä johtamismallin muutostarpeelle.

Toimintaympäristön muutos vaikuttaa taustalla tuoden myös johtamismallin muutostarpeen esiin. Yhtäältä kyse on paikallisen hallinnon puitteista ja rakenteista, mutta toisaalta myös niistä esimerkeistä, jotka toimivat ikään kuin impulsseina uudistamiskeskustelulle. Kansainvälisessä keskustelussa kyse on "eurooppa- 


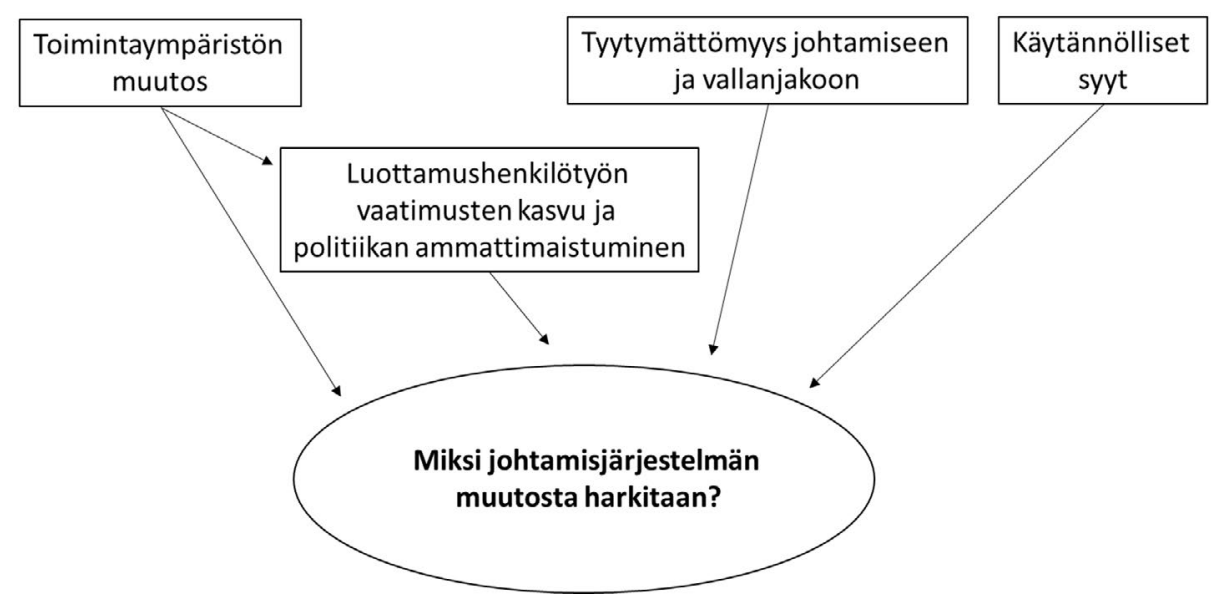

Kuvio 1. Analyysin tulokset kunnan johtamismallin muutostarpeeseen vaikuttavista tekijöistä.

laistumisesta" (ks. esim. Hambleton \& Sweeting 2004; Garmann 2015) ja kotimaisessa keskustelussa useimmiten niistä hyvistä kokemuksista, joita pormestarimallin myötä on kunnissa saatu. Toimintaympäristön muutos vaikuttaa myös epäsuorasti muutostarpeeseen, sillä omassa analyysissämme olennaisena tekijänä esiin nousi luottamushenkilötyön vaativuuden kasvu ja paikallispolitiikan ammattimaistuminen, jotka ovat kytköksissä laajasti kuntien toimintaympäristön monimutkaistumiseen ja muutoksen kiivauteen. Kokemukset luottamushenkilötyön edellytysten vaikeutumisesta lisäävät tarvetta tarkastella johtamismallin sopivuutta. Tältä osin olemme omalla analyysillämme kyenneet syventämään ja täydentämään kotimaiseen kontekstiin sovellettuna toimintaympäristön muutoksesta johtuvien syiden ymmärrystä.

Kansainvälisessä tutkimuksessa esiin nousseet johtamiseen ja vallanjakoon liittyvät ongelmat ja tyytymättömyys (ks. esim. Svara \& Watson 2010; Wollmann 2014; Sancino \& Castellani 2016) ovat monin eri tavoin läsnä myös suomalaisessa johtamismallikeskustelussa. Jännitteet viranhaltijoiden ja luottamushenkilöiden välisessä vallanjaossa ja etenkin poliittisen johdon kokemukset voimattomuudestaan voimakkaiden viranhaltijoiden rinnalla toimivat usein impulssina johtamismallin muutoskeskustelulle.

Vallanjakoon ja johtamiseen liittyvät ongelmat näyttävät suomalaisessa keskustelussa kulminoituvan poliittisiin viranhaltijoihin. Poliitti- sin perustein valitut virkajohtajat näkyvät aineistossamme ainakin kolmella tavalla johtamismallin muutoksesta käytävän keskustelun taustalla. Ensinnäkin, poliittiset virkanimitykset eivät välttämättä ole samassa rytmissä vaalien kanssa, jolloin kaupungin johtamisessa saattaa syntyä epäsuhta vaalien tuloksen ja johtajanpaikkojen välillä. Toiseksi, poliittisin perustein tehtävät virkanimitykset ovat helposti ristiriitojen ja tulkintaerimielisyyksien vuoksi vaikeita ja valintaperusteiden objektiivisuus ei välttämättä täysin toteudu. Kuitenkin virkajohtajan valinnassa ansioilla on oltava suuri merkitys eikä sitä voi puoluekirjalla korvata. Kolmanneksi, poliittiset virkanimitykset tasoittavat tietä pormestarimallille, mikä osaltaan voi selittää sitä, miksi pormestarimallista käydään vilkkainta keskustelua juuri suurissa kaupungeissa. Näissä poliittiset kaupungin- ja apulaiskaupunginjohtajat on jo pitkään valittu poliittisen sopimisen kautta, jolloin pormestarimalli vain tekee tästä prosessista entistä avoimempaa ja päästää myös kansalaiset - vähintään välillisesti - vaikuttamaan asiaan.

Analyysimme täydentää aiempaa tutkimusta korostaen luottamushenkilötyön vaativuuden kasvun merkitystä johtamismallin muuttamista koskevan keskustelun yhtenä käynnistävänä tekijänä. Lisäksi analyysimme tuo esiin käytännölliset syyt johtamismallin muutostarvetarkastelulle. Aiemmassa kansainvälisessä tutkimuksessa käytännölliset syyt eivät nouse lainkaan 
esiin. Analyysimme perusteella käytännölliset syyt liittyvät tilanteisiin, joissa kunnan toimintaa ja johtamista muutenkin uudistetaan tai tilanteisiin, jossa kunnanjohtaja on siirtynyt tai siirtymässä eläkkeelle tai muihin tehtäviin. Tällaisia tilanteita voi kuvata aikaikkunan avautumisena, jossa ikään kuin oheistuotteena selvitetään myös johtamismallin muuttamista.

Tutkimuksemme perusteella suomalaisessa johtamismallikeskustelussa korostuvat erityisesti paikalliset tarpeet, jotka usein liittyvät koettuihin ongelmiin paikallisessa johtamisessa tai vallanjaossa. Kunnan johtamismallin muuttaminen on perustavanlaatuisesti paikallinen asia. Näin on ollut myös esimerkiksi Isossa-Britanniassa, jossa valtiontason aloitteellisuudesta huolimatta johtamismallin muutostarve paikallistasolla aktivoituu erityisesti paikallisten olosuhteiden ja tilanteiden vuoksi (Fenwick \& Elcock 2014; Sweeting \& Hambleton 2020). Toimintaympäristön muutokset muuntuvat meillä paikalliseksi ymmärrykseksi kahdella tavalla: esimerkkien kautta, mutta etenkin luottamushenkilötyön vaativuuden kasvun ja siihen liittyvä paikallispolitiikan ammattimaistumisen kautta, mikä omassa aineistossamme korostui voimakkaasti.

Suomalaisessa johtamismallikeskustelussa valtio ei ole ollut kovinkaan aloitteellinen, kuten esimerkiksi Isossa-Britanniassa (Marsh 2012), vaan pikemminkin päinvastoin. Meillä kyse on ollut pääasiassa kuntatason tarpeista nousevassa aktiivisuudessa. Esimerkiksi pormestarimallin mahdollistavaan kuntalain muutokseen oli suuri vaikutus Tampereen kaupungin halulla siirtyä pormestarimalliin.

Johtamismallin valintaa koskeva paikallisuus korostuu myös siten, että puolueet ovat suomalaisessa keskustelussa ottaneet erilaisia kantoja pormestarimalliin paikallisesti eri kunnissa. Joissakin kunnissa esimerkiksi kokoomus on ollut aloitteellinen pormestarikeskustelujen käynnistämisessä, kun taas toisissa kunnissa aloite on tullut vaikkapa vihreiltä ja kokoomus on vastustanut johtamismallin muuttamista. Johtamismallin muutostarve ja siihen liittyvät kannat vaihtelevat siis kunnittain.

Tarve uudistaa johtamismallia tulee esiin monenlaisissa tilanteissa. Johtamismallin muutoskeskustelu tuo esiin suuret odotukset, joita kunnan johtamismalliin kytkeytyy; kunnan ylimmän johtajan varaan lasketaan paljon, ja siitä haetaan ratkaisua moniin isoihin kuntajohtamisen kysymyksiin. Taustalla voi olla kunnan ulkopuolelta tulevia asioita, mutta ennen kaikkea kyse on paikallisista, kunnan sisäisistä, kuntaorganisaation toimintaan, toimivuuteen, toimintaedellytyksiin ja toimijoihin liittyvistä kysymyksistä (ks. myös Jäntti, Haveri \& Airaksinen 2021).

Kunnan johtamismallin muuttamisesta etsitään apua niin isoihin toimintaympäristön muutokseen liittyviin kysymyksiin kuin vallanjaon, johtamisen ja toimintakulttuurin ongelmiin. Lisäksi johtamismallilla pyritään parantamaan luottamushenkilötyön edellytyksiä. Kunnan johtamismalli näyttäytyy tässä keskustelussa yleislääkkeenä, jonka avulla voidaan parantaa kunnan toimintaa ja johtamista.

Tällaiseen ajatteluun johtamismallista jonkinlaisena yleispätevänä vastauksena erilaisiin ongelmiin liittyy riskejä. Vaikka johtamismallilla on merkitystä monien asioiden kannalta, se ei ole riippumaton ja irrallinen selittävä tekijä, vaan se vaikuttaa yhteydessä monien muiden muuttujien kanssa. Siten samanlainen johtamismalli ei välttämättä toimi yhtä hyvin kaikissa kunnissa. Kunnan johtamismallin onnistuminen on kytköksissä aikaan ja paikkaan, tiettyihin kontekstuaalisiin tekijöihin kuten vallitseviin arvoihin ja toimintakulttuuriin, historiaan, poliittisiin voimasuhteisiin, henkilöstöön sekä johtajien osaamiseen ja persoonaan.

Tutkimuksemme korostaa sitä, että kunnan johtamismallin muuttaminen tai sen harkitseminen on leimallisesti ja perustavanlaatuisesti ennen kaikkea paikallinen kysymys, mikä on linjassa kuntajohtamisen kontekstisidonnaisuuden ja kuntajohtamisen paikallisten valintojen merkityksen kanssa. Kuntien erilaistumiskehityksen jatkuessa ja voimistuessa johtamismalleja koskevassa keskustelussa onkin hyvä muistaa, että mikään johtamismalli ei itsessään ole valmis ratkaisu kuntien ongelmiin, eikä kuntajohtamiseen ole olemassa yleispätevää erilaisiin kuntiin sellaisenaan sopivaa mallia. Sen sijaan malli voi mahdollistaa monenlaisia muutoksia, joiden myötä kunnan johtamista sekä eri toimijoiden välistä vuorovaikutusta ja yhteistyötä voidaan kehittää ja parantaa. Varsinaisen työn tekevät kaikissa malleissa kuitenkin ihmiset - yhdessä. 


\section{LÄHTEET}

Baldini, G. (2002). The direct election of mayors: an assessment of the institutional reform following the Italian municipal elections of 2001. Journal of Modern Italian Studies, 7(3), 364-379. DOI: $10.1080 / 1354571021000026616$

Banfield, E. C. \& Wilson, J. Q. (1963). City politics. New York: Vintage Books.

Carr, J. B. (2015). What Have We Learned about the performance of Council-Manager Government? A Review and Synthesis of the Research. Public Administration Review. 75(5), 673-689. DOI: 10.1111/puar.12415

Choi, C. G., Feiock, R. C. \& Bae, J. (2013). The Adoption and Abandonment of CouncilManager Government. Public Administration Review 73(5), 727-36. DOI: 10.1111/puar.12097

Copus, C. (2004). Directly Elected Mayors: A Tonic for Local Governance or Old Wine in New Bottles? Local Government Studies, 30(4), 576588.

DOI: $10.1080 / 0300393042000318003$

Department of Communities and Local Government (2011). Localism Bill: creating executive mayors in the 12 largest English cities Impact assessment. http://www.parliament.uk/ documents/impact-assessments/IA11-010AL. pdf

Feiock, R., Jeong, M. G. \& Kim, J. (2003). Credible Commitment and Council-Manager Government: Implications for Policy Instrument Choices. Public Administration Review, 63(5), 616-625.

DOI: $10.1111 / 1540-6210.00324$

Fenwick, J. \& Elcock, H. (2016). Elected mayors in England: leaders or managers? International Journal of Public Leadership, 12(4), 289-300. DOI: 10.1108/IJPL-04-2016-0018

Fenwick, J. \& Elcock, H. (2014). Elected Mayors: LeadingLocally?LocalGovernmentStudies, 40(4), 581-599. DOI: 10.1080/03003930.2013.836492

Fereday, J. \& Muir-Cochrane, E. (2006). Demonstrating Rigor Using Thematic Analysis: A Hybrid Approach of Inductive and Deductive Coding and Theme Development. International Journal of Qualitative Methods 5(1), 80-92. DOI: 10.1177/160940690600500107

Frederickson, H. G., Johnson, G. A., \& Wood, C. H. (2004b). The changing structure of American cities: A study of the diffusion of innovation. Public Administration Review, 64(3), 320-330. DOI: $10.1111 / j .1540-6210.2004 .00376 . x$

Frederickson, H. G., Wood, C., \& Logan, B. (2001). How American city governments have changed: The evolution of the Model
City Charter. National Civic Review, 90(1), 3-18. DOI: $10.1002 /$ ncr.90101

Garmann, S. (2014). Elected or Appointed? How the Nomination Scheme of the City Manager Influences the Effects of Government Fragmentation. Journal of Urban Economics, 86(1). DOI: 10.1016/j.jue.2014.12.004

Goldsmith, M. \& Larsen, H. (2004). Local Political Leadership: Nordic Style. International Journal of Urban and Regional Research, 28(1), 121-133. DOI: $10.1111 /$ j.0309-1317.2004.00506.x

Guérin, E. \& Kerrouche, É. (2008). From Amateurs to Professionals: The Changing Face of Local Elected Representatives in Europe. Local Government Studies, 34(2),179-201.

DOI: $10.1080 / 03003930701852260$

Hakari, K. (2009). Tampereen toimintamallin uudistus - vastaus tulevaisuuden haasteisiin. Teoksessa Haveri, A., Majoinen, K. \& Jäntti, A. (toim.), Haastava kuntajohtaminen. (s. 84-92). Helsinki: Suomen Kuntaliitto.

Hakari, K., Stenvall, J. \& Rannisto, P-H. (2013). Pormestarimalli ja kaupungin johtamisen muutos - Uuden julkisen hallinnan näkökulma. Hallinnon Tutkimus, 32(2), 129-145.

Hambleton, R. (2013). Elected mayors: an international rising tide? Policy \& Politics, 41(1),125128. DOI: $10.1332 / 030557313$ X663279

Hambleton, R. \& Sweeting, D. (2004). U.S. Style Leadership for English Local Government? Public Administration Review, 64(4), 474-488. DOI: 10.1111/j.1540-6210.2004.00393.x

Hassett, W., \& Watson, D. (2007). Civic battles: When cities change their form of government. Boca Raton: Pr Academics Press.

Heinelt, H., Hlepas, N., Kuhlmann, S. \& Swianiewicz, P. (2018). Local Government Systems: Grasping the Institutional Environment of Mayors. Teoksessa Heinelt, H., Magnier, A., Cabria, M. \& Reynaert, H. (toim.), Political Leaders and Changing Local Democracy. Governance and Public Management, (s. 19-78). Palgrave Macmillan, Cham.

DOI: 10.1007/978-3-319-67410-0_2

Juntunen, P. \& Leinonen, J. (2007). Mayor as City Manager. Current Topics and New Points of Development in Finnish Local Government. Teoksessa Juntunen, P. \& Leinonen, J. (toim.), Exploring Finnish Local and Regional Administration - Some Current Perspectives. Rovaniemi: Faculty of Social Sciences, University of Lapland.

Jäntti, A., Haveri, A. \& Airaksinen, J. (2021). Pormestarimalli kuntajohtamisen muotona - pormestarimalliin liittyvät tavoitteet, odotukset 
ja uskomukset. Politiikka 63(2), 135-157.

DOI:10.37452/politiikka.101245

Kreft, S. F. (2007). An Efficiency Comparison of City Managers and Elected Mayors. Kelley School of Business, Indiana University. https://kelley. iu.edu/riharbau/RePEc/iuk/wpaper/bepp200702-kreft.pdf

Larsen, H. O. (2002). Directly Elected Mayors - Democratic Renewal or Constitutional Confusion? Teoksessa Caulfield, J. \& Larsen, H. O. (toim.), Local Government at the Millenium. (s. 111-133). Urban Research International. Wiesbaden: VS Verlag für Sozialwissenschaften. DOI: 10.1007/978-3-663-10679-1_6

Leinonen, J. (2010). Kunnanjohtaja johtamisjärjestelmän kehittämisen aallokossa - kunnan poliittisen johtajuuden vahvistamistarpeet kunnanjohtajan näkökulmasta. Kunnallistieteellinen Aikakauskirja, 38(2), 140-156.

Lodge, G. (2012). Mayors and democratic renewal in England. Teoksessa Gash, T. \& Sims, S. (toim.), What Can Elected Mayors Do for Our Cities? (s. 29-33). London: Institute for Government.

Magnier, A. (2006). Strong Mayors? On Direct Election and Political Entrepreneurship. Teoksessa Bäck, H., Heinelt, H. \& Magnier, A. (toim.), The European Mayor (s. 353-376). Wiesbaden: VS Verlag für Sozialwissenschaften. DOI: 10.1007/978-3-531-90005-6_16

Marsh, A. (2012). Is it time to put the dream of elected mayors to bed? Policy and Politics, 40(4), 607-611. DOI: 10.1332/030557312X657808

Nelson, K. L. \& Afonso, W. B. (2019). Ethics by Design - The Impact of Form of Government on Municipal Corruption. Public Administration Review, 79(4), 591-600.

DOI: $10.1111 /$ puar. 13050

Sancino, A. \& Castellani, L. (2016). New development: Directly elected mayors in Italy -creating a strong leader doesn't always mean creating strong leadership. Public Money \& Management, 36(2), 153-156.

DOI: 10.1080/09540962.2016.1118945

Sandberg, S. (2016). Kunnallisten luottamushenkilöiden ajankäyttö vuosina 1995-2015. ARTTU2-tutkimusohjelman julkaisusarja nro 5/2016. Helsinki: Suomen Kuntaliitto.

Schaap, L., Daemen, H. \& Ringeling, A. (2009). Mayors in Seven European Countries: Part II - Performance and Analysis. Local Government Studies, 35(2), 235-249.

DOI: $10.1080 / 03003930902743029$

Stenvall, J. \& Airaksinen, J. (2009). Manse mallillaan - Tampereen mallin arviointi ja palvelu- innovaatiot. Acta 211. Helsinki: Suomen Kuntaliitto.

Svara, J. H. (2003). Effective Mayoral Leadership in Council-Manager Cities: Reassessing the Facilitative Model. National Civic Review, 92(2), 157-172. DOI: $10.1002 /$ ncr. 14

Svara, J. H., \& Watson, D. J. (2010). More than mayor or manager: Campaigns to change form of government in America's large cities. Washington, DC: Georgetown University Press.

Sweeting, D. (2003). How strong is the Mayor of London? Policy \& Politics, 31(4), 465-478.

DOI: $10.1332 / 030557303322439353$

Sweeting, D. \& Hambleton, R. (2020). The dynamics of depoliticisation in urban governance: Introducing a directly elected mayor. Urban Studies, 57(5), 1068-1086.

DOI: $10.1177 / 0042098019827506$

Wenchi, W., Butler, J. S. \& Jennings Jr, E. T. (2019). The Determinants of Municipal Structures on a Political-Administrative Dimension. American Review of Public Administration, 49(2), 189-202. DOI: $10.1177 / 0275074018814876$

Wollmann, H. (2004). Urban leadership in German local politics: the rise, role and performance of the directly elected (chief executive) mayor. International Journal of Urban and Regional Research, 28(1), 150-164.

DOI: $10.1111 /$ j.0309-1317.2004.00508.x

Wollmann, H. (2014). The directly-elected mayor in the German Länder - introduction, implementation and impact, Public Money \& Management, 34(5), 331-337.

DOI: $10.1080 / 09540962.2014 .945798$

\section{MEDIA-AINEISTOLÄHTEET}

HS/Jokinen, R. (2007) Pekka Korpinen jättää Helsingin apulaiskaupunginjohtajan tehtävän. HS Kaupunki 31.7.2007. https://www.hs.fi/kaupunki/art-2000004500646.html

HS/Laitinen, J. (2015) Pormestarin valinta vaikuttaa varmalta - mitä se tarkoittaa helsinkiläisten kannalta? HS Kaupunki/HS-Analyysi 24.11.2015.

https://www.hs.fi/kaupunki/art2000002868312.html

HS/Lehtinen, T. (2015) Turkua johtaa ehkä jatkossa pormestari. HS Kotimaa 9.9.2015. https:// www.hs.fi/kotimaa/art-2000002851180.html

HS/Moisio, T. (2007) Espoo ja Vantaa harkitsevat pormestaria poliittiseen johtoon. HS Kaupunki 20.9.2007.

https://www.hs.fi/kaupunki/art2000004512813.html 
HS/Saarelainen (2001) Vihtiläiset saattavat valita pormestarin kunnan johtoon. HS Kaupunki 30.9.2001.

https://www.hs.fi/kaupunki/art2000004000341.html

HS/Salomaa, M. (2016) Helsingistä tulee Suomen kolmas pormestarin johtama kaupunki. HS Kaupunki 22.6.2016. https://www.hs.fi/kaupunki/art-2000002907645.html

Yle/Frilander, J. (2012) Vihreät: kaupunginjohtajavalinta tappio demokratialle. Yle Uutiset, Kotimaa 26.4.2012. https://yle.fi/uutiset/3-6072211

Yle/Haapanen, L. (2016) Rovaniemen perussuomalaiset: Kaupunki tarvitsee pormestarin. Yle Uutiset, Pormestarit 11.4.2016. https://yle.fi/uutiset/3-8802682

Yle/Hjelt, Y. (2015) Vihreät haluaa Saloon pormestarin. Yle Uutiset, Kotimaa 2.2.2015. https://yle.fi/uutiset/3-7774870

Yle/ Joki, N. (2012) Perussuomalaiset haluaa Kotkaan pormestarin. Yle Uutiset, Pormestarit, 24.5.2012. https://yle.fi/uutiset/3-6108770

Yle/Kivioja, K. (2015) Kokkola on räätälöimässä omannäköistä johtajaa - puhdas pormestarimalli ei saa suurta kannatusta. Yle Uutiset, Politiikka 23.7.2015.

https://yle.fi/uutiset/3-8163526

Yle/Koskinen, T. (2016) Pormestariruletti pyörähtää kunnolla käyntiin - Sauri ja Sarkomaa kertovat omat valttinsa kisassa Helsingin ykköspestistä. Yle Uutiset, Kotimaa 9.9.2016. https://yle.fi/uutiset/3-9152935
Yle/Lassheikki, P. (2012) Kotkan suuret ryhmät eivät lämpene pormestarimallille. Yle Uutiset, Pormestarit, 24.5.2012. https://yle.fi/uutiset/3-6109897

Yle/Matson-Mäkelä, K. (2013) Pormestari myös Nokialle? Yle Uutiset, Politiikka 22.3.2013. https://yle.fi/uutiset/3-6549511

Yle/Niemistö, E. (2019) Pormestari vai kaupunginjohtaja? Seinäjoki linjaa tänään tulevan johtamismallin. Yle Uutiset, Kunnallishallinto 16.12.2019. https://yle.fi/uutiset/3-11120122

Yle/Sipola, T. (2017) Pukkaako Ouluun pormestaria? "Niin epäselvä rooli, että eipä ole mielenkiintoa lähteä yrittämään". Yle Uutiset, Valta 7.4.2017. https://yle.fi/uutiset/3-9358244

Yle/Turtola, I. (2016) Pormestari kunnan johtopaikalla on vielä harvinaisuus - nyt sellaista miettii Tuusula. Yle Uutiset, Kotimaa 9.5.2016. https://yle.fi/uutiset/3-8863942

Yle/Turtola, K. (2017) Pikkukunta havittelee pormestaria. Yle Uutiset, Kärkölä 5.12.2017. https://yle.fi/uutiset/3-9963162

Yle Uusimaa (2009) Vihreät haluaa Espooseen pormestarin. Yle Uutiset, Pormestarit 27.5.2009. https://yle.fi/uutiset/3-5257002

Yle/Vesalainen, S. \& Sarolahti, M. (2017) Dramaattinen yllätys viime tipassa: Kokoomuksen ääniharavat jätettiin rannalle Tuusulassa. Yle Uutiset, Tuusula 1.3.2017. https://yle.fi/uutiset/3-9485220 